\title{
Evaluation of Addition of Low Dose Midazolam to a Mixture of Low Dose Ketamine and Hyperbaric Bupivacaine Given in Subarachnoid Block in Patients Undergoing Lower Limb Orthopaedic Surgery
}

\author{
Authors \\ Dr Jalpa C. Balat ${ }^{1}$, Dr Sushil M. Damor (M.S., FMAS, FIAGES) ${ }^{2}$, Dr Arnab Sarkar \\ ${ }^{1}$ Assistant Professor, Dept. of Anaesthesiology, S.S.G. Hospital and Baroda Medical College, Vadodara \\ ${ }^{2}$ Assistant Professor, Dept. of General Surgery, S.S.G. Hospital and Baroda Medical College, Vadodara \\ ${ }^{3}$ Resident Doctor, Dept. of General Surgery, S.S.G. Hospital and Baroda Medical College, Vadodara \\ Corresponding Author
}

Dr Sushil M. Damor (M.S., FMAS, FIAGES)

B-26, Navrang Society, Karodia Road, Gorwa, Vadodara- 390016

Email: sushil.damor@gmail.com

\begin{abstract}
Background: Dr Bion used Ketamine first time intrathecally in patients wounded during war time. Intrathecal ketamine produced significant analgesia with stable haemodynamics. Combination of intrathecal Ketamine and Midazolam with Bupivacaine might have the advantages of Stable haemodynamics, prolonged duration of analgesia, synergism could reduce dose requirements, increase therapeutic index and reduce toxicity.

Aims and Objectives: To evaluate addition of low dose Midazolam to a mixture of low dose Ketamine and Hyperbaric Bupivacaine in subarachnoid block in patients undergoing lower limb orthopedic surgery to study spinal blockade characteristic, duration and quality of analgesia and side effect profile in addition to post operative analgesia.

Materials and Methods: A randomized study was carried out in the Department of Anaesthesiology, Govt. Medical College and SSG Hospital, Baroda between the periods of July 2009 to Feb 2010 with 60 patients, 30 in each group of both sexes.

Results and Conclusions: Combination of Ketamine in low dose with Bupivacaine provides stable haemodynamics without any behavioural and central side effects. Addition of Midazolam in low dose to a mixture of low dose Ketamine and Bupivacaine when given intrathecally prolongs the duration of surgical anaesthesia and pain free interval without affecting the other parameters and complications of subarachnoid block.

Keywords: Ketamine, Midazolam, Heavy bupivacaine, Subarachnoid block, Intrathecal.
\end{abstract}

\section{Introduction}

Spinal anaesthesia has many advantages for lower abdominal and lower limb surgeries. Commonly used agents in spinal anaesthesia are Lignocaine and Bupivacaine. Major problems associated with them are hypotension and short duration of post operative analgesia. Adjuvants used to overcome this problems are Epinephrine, Ketamine, Midazolam, Clonidine, Opioids and Neostigmine. Dr Bion used Ketamine first time intrathecally in patients wounded during war time. Intrathecal ketamine produced significant analgesia with 
stable haemodynamics. Higher incidence of central adverse events and poor patient satisfaction limit its intrathecal use. Midazolam has spinally mediated antinociceptive effect. Intrathecal midazolam improves duration and quality of spinal anaesthesia. Duration of postoperative analgesia is significantly prolonged by addition of midazolam intrathecally. Combination of intrathecal Ketamine and Midazolam with Bupivacaine might have the advantages of Stable haemodynamics, prolonged duration of analgesia, synergism could reduce dose requirements, increase therapeutic index and reduce toxicity.

Hence, we planned to evaluate addition of low dose Midazolam $(0.02 \mathrm{mg} / \mathrm{kg})$ to a mixture of low dose Ketamine $(0.1 \mathrm{mg} / \mathrm{kg})$ and Hyperbaric Bupivacaine $0.5 \%(3 \mathrm{ml})$ in subarachnoid block in patients undergoing lower limb orthopedic surgery to study spinal blockade characteristic, duration and quality of analgesia and side effect profile in addition to post operative analgesia.

Our primary aim of this study was to evaluate Pain free interval. While our secondary aims were to evaluate spinal block characteristics and haemodynemic stability as well as to evaluate any post operative complications in terms of behavioral and neurological incidents.

Following parameters were observed for the evaluation: 1) Onset and duration of sensory block, 2) Onset and duration of motor block, 3)Level of sedation, 4)Vital parameters like pulse rate, blood pressure, respiratory rate and oxygen saturation, 5) Duration of pain free interval and analgesic requirement in $24 \mathrm{hr}$ post operative period and 6) Side effects occurring during intra and post operative period.

\section{Materials and Methods}

A randomized study was carried out in the Department of Anaesthesiology, Govt. Medical College and SSG Hospital, Baroda between the periods of July 2009 to Feb 2010 with 60 patients, 30 in each group of both sexes.
History was taken regarding present and past complaints, personal history, medication history, history of previous anaesthesia exposure, blood transfusion, drug allergy. Neurological disease, etc. general and systemic examination was done. Routine and specific investigations were carried out.

Inclusion criteria included: Pateints with age 18$60 \mathrm{yrs}$, ASA Grade I and II and patients posted for lower limb orthopaedic surgery.

Exclusion criteria included: Patients not willing to participate in study, patients with bleeding disorder, patients with severe deformity of spine, local infection in region of lumbar spine, morbidly obese patients, patients with neurological disease, psychiatric illness, epilepsy in the past, history of drug allergy to drug under study and patients unable to understand pain scales.

All the selected patients were explained about the purpose, procedure and side effects of the study. They were also explained about assessment of pain with the help of Visual Analogue Scale. After this a written and informed consent was taken.

\section{Anaesthetic procedure}

Patient was given no premedication. After taking Intravenous line with $18 / 20 \quad G$ intravenous cannula, preloading was done with Inj Ringer Lactate $10 \mathrm{ml} / \mathrm{kg}$ over a period of 20 minutes before giving spinal block. Patients were assigned randomly in one of the following two groups.

GROUP K: patient receiving Inj Hyperbaric Bupivacaine $0.5 \% 3 \mathrm{cc}+$ Inj Ketamine $(0.1 \mathrm{mg} / \mathrm{kg})$ GROUP MK: patient receiving Inj Hyperbaric Bupivacaine $0.5 \% 3 \mathrm{cc}+$ Inj Ketamine $(0.1 \mathrm{mg} / \mathrm{kg})$ + Inj Midazolam $(0.02 \mathrm{mg} / \mathrm{kg})$

All the injection used were preservative free and the solution was made to equal volume of $3.5 \mathrm{cc}$ by adding $0.9 \%$ normal saline. We used tuberculin syringe to measure exact amount of Ketamine and Midazolam.

After taking the patient in operating theatre, monitors like NIBP (non invasive blood pressure) and pulse oximeter were attached. Base line pulse 
rate, blood pressure, respiratory rate, oxygen saturation was noted down.

After checking basic necessities like anaesthesia trolley, resuscitation drugs, and suction apparatus spinal anaesthesia was given using 23 G spinal needle in sitting position. Space chosen and time of drug injection were noted down. Observations were recorded as shown below. Patient having no or inadequate surgical anaesthesia were excluded from the study. Post operatively patient was observed for $24 \mathrm{hr}$ for any complications.

\section{Observations}

1) Sensory block: was checked by using pin prick method- Onset of sensory block (at the level of L1 dermatome), Duration of sensory block (time interval from onset to when sensation felt at L1 dermatome again), Duration of pain free interval (time interval from onset of sensory block to when first rescue analgesic given).

2) Motor block: was assessed by Bromage scale- Onset of motor block (time to attain Bromage grade 3), Duration of motor block (time interval from onset to when Bromage grade become 0 again)

Grade 0: no motor block

Grade 1: unable to flex hip

Grade 2: unable to flex knee

Grade 3: unable to flex ankle

3) Sedation score: Level of sedation was assessed on four point scoring system

Score 0: No sedation (Awake)

Score 1: Asleep but arousable by using verbal command

Score 2: Asleep and not arousable by using verbal command but responds to painful stimulus

Score 3: unresponsive to painful stimulus

4) Vital parameters: Pulse rate, blood pressure, respiratory rate, oxygen saturation were monitored. Recording was done before giving block and then at 1, 5, 10 and 15 minutes after giving the block. Then every 15 min till the end of surgery.
5) Duration of surgery: was also noted

6) Post Operative Period: Vital parameters were recorded initially at $30 \mathrm{~min}$ interval for $6 \mathrm{hr}$ then at $1 \mathrm{hr}$ interval for $12 \mathrm{hrs}$. Pain assessment was done every half hourly for initial $6 \mathrm{hr}$ then hourly for $24 \mathrm{hr}$ by using Visual Analogue Scale (VAS). The duration of effective analgesia or pain free interval was counted from onset of sensory block to when VAS score of 4 or more. At this time, patients were given rescue analgesic Inj Diclofenac Sodium $1.5 \mathrm{mg} / \mathrm{kg}$ IM. Number and time of rescue analgesic required in $24 \mathrm{hr}$ post operative period also noted down.

7) Intra and post operative complications: Patients were monitored for various intra and post operative complications: 1) Bradycardia: defined as pulse rate less than $20 \%$ of preoperative value. It was treated with Inj Atropine 0.6MG IV bolus. 2) Hypotension: defined as systolic blood pressure $<20 \%$ of pre-procedure value. Inj Mephentermine $5 \mathrm{mg}$ IV bolus given when hypotension occurs. 3) Respiratory Depression: defined as respiratory rate less than $10 /$ min or oxygen saturation less than $90 \%$. It was to be treated with oxygen if required. 4) Nausea and Vomiting 5) Shivering and Rigors 6) Hallucination, emergence phenomenon 7) Post Dural Puncture Headache 8) Backache 9) Urinary retention and 10) Neurological and Behavioral side effects.

8) Analysis of results: Mean and standard values were taken out. Analysis of variance (ANOVA) of the data for the various parameters was done using student's paired t-test for intra group comparison and unpaired t-test for intergroup comparison. $\mathrm{P}<0.05$ was considered to be significant. 
Observations and Results

Table 1: Demographic Data

\begin{tabular}{l|c|c|}
\hline & GROUP MK $(\mathrm{N}=30)$ & GROUP K $(\mathrm{N}=30)$ \\
AGE $($ YEARS MEAN \pm SD) & $36.92 \pm 12.25$ & $30.9 \pm 8.42$ \\
SEX $($ M:F $)$ & $24: 6$ & $23: 7$ \\
HEIGHT $(\mathrm{CM})$ & $166.17 \pm 3.57$ & $166.56 \pm 5.31$ \\
\hline WEIGHT $(\mathrm{KG})$ & $55.33 \pm 5.71$ & $56.33 \pm 4.90$ \\
\hline ASA $(1: 2)$ & $30: 0$ & $30: 0$ \\
\hline
\end{tabular}

There were no statistical differences in demographic data between two groups.

The onset of sensory and motor was faster in Group MK. Also duration of sensory and motor block was prolonged in Group MK compared to Group K. Surgical anaesthesia was adequate in all the cases and there was not a single failure case in either of the two groups.

Table 2: Block Characteristics

\begin{tabular}{|c|c|c|c|}
\hline PARAMETER & GROUP MK & GROUP K & $\begin{array}{l}\text { P VALUE } \\
\text { SIGNIFICANCE }\end{array}$ \\
\hline $\begin{array}{l}\text { ONSET OF SENSORY BLOCK } \\
(\mathrm{MIN})(\mathrm{MEAN} \pm \mathrm{SD})\end{array}$ & $1.99 \pm 0.44$ & $3.38 \pm 0.66$ & $\mathrm{p}<0.001$ \\
\hline $\begin{array}{l}\text { ONSET OF MOTOR B LOCK } \\
(\mathrm{MIN})(\mathrm{MEAN} \pm \mathrm{SD})\end{array}$ & $6.03 \pm 1.13$ & $7.30 \pm 1.06$ & $\mathrm{p}<0.001$ \\
\hline $\begin{array}{l}\text { DURATION OF SENSORY } \\
\text { BLOCK }(M I N)(M E A N \pm S D) *\end{array}$ & $151.83 \pm 18.29$ & $115.77 \pm 13.09$ & $p<0.001$ \\
\hline $\begin{array}{l}\text { DURA TION OF MOTOR } \\
\text { BLOCK }(M I N)(\text { MEAN } \pm \text { SD) }\end{array}$ & $230.23 \pm 29.06$ & $198.07 \pm 11.15$ & $p<0.001$ \\
\hline
\end{tabular}

Table 3A: Changes in Mean Pulse Rate

\begin{tabular}{|c|c|c|c|c|c|}
\hline \multicolumn{3}{|c|}{ GROUP MK } & \multicolumn{3}{|c|}{ GROUP K } \\
\hline TIME & $\begin{array}{l}\text { PULSE } \\
\text { RATE/MIN } \\
(\mathrm{MEAN} \pm \text { SD) }\end{array}$ & $\begin{array}{l}\text { INTRA-GROUP } \\
\text { COMPARISON P } \\
\text { VALUE } \\
\text { SIGNIFICANCE }\end{array}$ & $\begin{array}{l}\text { PULSE } \\
\text { RATE/MIN } \\
(\text { MEAN } \pm \text { SD) }\end{array}$ & $\begin{array}{l}\text { INTRA-GROUP } \\
\text { COMPARISON P } \\
\text { VALUE } \\
\text { SIGNIFICANCE }\end{array}$ & $\begin{array}{l}\text { INTER- GROUP } \\
\text { COMPARISON P } \\
\text { VALUE } \\
\text { SIGNIFICANCE }\end{array}$ \\
\hline $\begin{array}{l}\text { PRE } \\
\text { BLOCK }\end{array}$ & $84.47 \pm 7.20$ & & $85.47 \pm 4.87$ & & $p>0.05$ \\
\hline \multicolumn{6}{|c|}{ POST BLOCK } \\
\hline $1 \mathrm{MIN}$ & $84.53 \pm 6.89$ & $\mathrm{p}>0.05$ & $85.47 \pm 4.87$ & $\mathrm{p}>0.05$ & $p>0.05$ \\
\hline $5 \mathrm{MIN}$ & $84.40 \pm 7.44$ & $p>0.05$ & $85.87 \pm 5.97$ & $\mathrm{p}>0.05$ & $p>0.05$ \\
\hline $10 \mathrm{MIN}$ & $83.20 \pm 8.04$ & $p>0.05$ & $86.20 \pm 5.37$ & $\mathrm{p}>0.05$ & $p>0.05$ \\
\hline $15 \mathrm{MIN}$ & $82.93 \pm 7.37$ & $p>0.05$ & $85.67 \pm 5.71$ & $\mathrm{p}>0.05$ & $p>0.05$ \\
\hline $30 \mathrm{MIN}$ & $82.80 \pm 6.84$ & $p>0.05$ & $85.40 \pm 5.46$ & $\mathrm{p}>0.05$ & $p>0.05$ \\
\hline $60 \mathrm{MIN}$ & $83.93 \pm 6.44$ & $p>0.05$ & $85.33 \pm 5.42$ & $p>0.05$ & $p>0.05$ \\
\hline $90 \mathrm{MIN}$ & $84.67 \pm 5.95$ & $p>0.05$ & $85.00 \pm 5.25$ & $p>0.05$ & $p>0.05$ \\
\hline $120 \mathrm{MN}$ & $84.67 \pm 5.95$ & $p>0.05$ & $85.00 \pm 5.25$ & $\mathrm{p}>0.05$ & $p>0.05$ \\
\hline $150 \mathrm{MN}$ & $84.57 \pm 5.92$ & $p>0.05$ & $84.80 \pm 5.16$ & $p>0.05$ & $p>0.05$ \\
\hline
\end{tabular}

This table shows changes in mean pulse rate after giving spinal anaesthesia. In both the groups, the intra-group and inter-group comparison did not show any significant change in mean pulse rate throughout the study when compared with preoperative values. 
Table 3B: Changes in Mean Systolic Blood Pressure

\begin{tabular}{|c|c|c|c|c|c|}
\hline \multirow[b]{2}{*}{ TIME } & \multicolumn{2}{|c|}{ GROUP MK } & \multicolumn{2}{|c|}{ GROUP K } & \multirow[b]{2}{*}{$\begin{array}{l}\text { INTER- GROUP } \\
\text { COMPARISON P } \\
\text { VALUE } \\
\text { SIGNIFICANCE }\end{array}$} \\
\hline & $\begin{array}{l}\text { SYSTOLIC } \\
\text { BLOOD } \\
\text { PRESSURE } \\
(\mathrm{mmHg}) \\
(\mathrm{ME} A N \pm \text { SD) }\end{array}$ & $\begin{array}{l}\text { INTRA-GROUP } \\
\text { COMPARISON P } \\
\text { VALUE } \\
\text { SIGNIFICANCE }\end{array}$ & $\begin{array}{l}\text { SYST OLIC } \\
\text { BLOOD } \\
\text { PRRSSURE } \\
\text { (mmHg) } \\
(\mathrm{MEAN} \pm \text { SD) }\end{array}$ & $\begin{array}{l}\text { INTRA-GROUP } \\
\text { COMPARISON P } \\
\text { VALUE } \\
\text { SIGNIFICANCE }\end{array}$ & \\
\hline $\begin{array}{l}\text { PRE } \\
\text { BLOCK }\end{array}$ & $119.33 \pm 8.23$ & & $117.5 \pm 7.51$ & & $P=0.05$ \\
\hline \multicolumn{6}{|c|}{ POST BLOCK } \\
\hline $1 \mathrm{MN}$ & $118.63 \pm 9.69$ & $\mathrm{P}>0.05$ & $117.5 \pm 7.51$ & $\mathrm{P}>0.05$ & $P>0.05$ \\
\hline $5 \mathrm{MN}$ & $114.67 \pm 9.59$ & $p<0.05$ & $116.37 \pm 6.94$ & $P>0.05$ & $P=0.05$ \\
\hline $10 \mathrm{MN}$ & $111.33 \pm 9.88$ & $p=0.001$ & $114.97 \pm 6.76$ & $P=0.05$ & $P=0.05$ \\
\hline $15 \mathrm{MN}$ & $110.67 \pm 10.35$ & $p<0.001$ & $114.27 \pm 6.18$ & $\mathrm{P}>0.05$ & $P=0.05$ \\
\hline $30 \mathrm{MN}$ & $111.00 \pm 9.54$ & $p<0.001$ & $113.67 \pm 6.69$ & $\mathrm{P}<0.05$ & $P=0.05$ \\
\hline $60 \mathrm{MIN}$ & $112.00 \pm 8.60$ & $\mathrm{p}=0.001$ & $113.67 \pm 6.69$ & $\mathrm{P}<0.05$ & $P=0.05$ \\
\hline $90 \mathrm{MIN}$ & $111.00 \pm 8.68$ & $p<0.001$ & $113.67 \pm 6.69$ & $\mathrm{P}<0.05$ & $\mathrm{P}>0.05$ \\
\hline $120 \mathrm{MN}$ & $111.00 \pm 8.55$ & $p<0.001$ & $113.83 \pm 6.78$ & $P>0.05$ & $P>0.05$ \\
\hline $150 \mathrm{MN}$ & $111.33 \pm 8.68$ & $p<0.001$ & $113.83 \pm 6.78$ & $P>0.05$ & $P>0.05$ \\
\hline
\end{tabular}

In Group MK the intra-group comparison showed highly significant fall in systolic blood pressure 10 min after giving the block then remained so till the end of surgery. On the other hand, intra-group comparison in Group K showed no significant fall in systolic blood pressure. The inter-group comparison of systolic blood pressure between
Group MK and Group K showed no significant difference throughout the study.

Thus less fluctuation in systolic blood pressure occur in patients of Group K. While patients in Group MK showed significant fall in systolic blood pressure.

Table 3C: Changes in Mean Diastolic Blood Pressure

\begin{tabular}{|c|c|c|c|c|c|}
\hline \multirow[b]{2}{*}{ TIME } & \multicolumn{2}{|c|}{ GROUP MK } & \multicolumn{2}{|c|}{ GROUP K } & \multirow[b]{2}{*}{$\begin{array}{l}\text { INTE R- GROUP } \\
\text { COMPARISON } \\
\text { P VALUE } \\
\text { SIGNIFICANCE }\end{array}$} \\
\hline & $\begin{array}{l}\text { DIASTOLIC } \\
\text { BLOOD } \\
\text { PRESSURE } \\
(\text { mmHg) } \\
(\text { MEAN } \pm \text { SD) }\end{array}$ & $\begin{array}{l}\text { INTRA-GROUP } \\
\text { COMPARISON } \\
\text { P VALUE } \\
\text { SIGNIFICANCE }\end{array}$ & $\begin{array}{l}\text { DIASTOLIC } \\
\text { BLOOD } \\
\text { PRRSSURE } \\
(\text { mmHg) } \\
(\text { MEAN } \pm \text { SD) }\end{array}$ & $\begin{array}{l}\text { INTRA-GROUP } \\
\text { COMPARISON } \\
\text { P VALUE } \\
\text { SIGNIFICANCE }\end{array}$ & \\
\hline $\begin{array}{l}\text { PRE } \\
\text { BLOCK }\end{array}$ & $76.00 \pm 6.75$ & & $74.33 \pm 8.58$ & & $P>0.05$ \\
\hline \multicolumn{6}{|c|}{ POST BLOCK } \\
\hline $1 \mathrm{MIN}$ & $75.87 \pm 6.70$ & $\mathrm{P}>0.05$ & $74.33 \pm 8.58$ & $\mathrm{P}>0.05$ & $P=0.05$ \\
\hline $5 \mathrm{MIN}$ & $73.33 \pm 8.02$ & $P>0.05$ & $73.33 \pm 8.30$ & $P>0.05$ & $P>0.05$ \\
\hline $10 \mathrm{MIN}$ & $70.43 \pm 8.68$ & $\mathrm{P}<0.05$ & $73.00 \pm 8.12$ & $\mathrm{P}>0.05$ & $P>0.05$ \\
\hline $15 \mathrm{MIN}$ & $70.33 \pm 8.49$ & $\mathrm{P}<0.05$ & $72.30 \pm 7.58$ & $\mathrm{P}>0.05$ & $P>0.05$ \\
\hline $30 \mathrm{MIN}$ & $69.93 \pm 7.80$ & $\mathrm{P}<0.05$ & $72.20 \pm 7.64$ & $\mathrm{P}>0.05$ & $P>0.05$ \\
\hline $60 \mathrm{MIN}$ & $69.67 \pm 7.65$ & $\mathrm{p}=.001$ & $72.20 \pm 7.61$ & $\mathrm{P}>0.05$ & $P>0.05$ \\
\hline $90 \mathrm{MIN}$ & $70.00 \pm 7.88$ & $\mathrm{P}<0.05$ & $72.00 \pm 7.61$ & $\mathrm{P}>0.05$ & $P>0.05$ \\
\hline $120 \mathrm{MIN}$ & $70.00 \pm 7.88$ & $\mathrm{P}<0.05$ & $72.00 \pm 7.61$ & $P>0.05$ & $P>0.05$ \\
\hline $150 \mathrm{MIN}$ & $70.33 \pm 7.65$ & $P<0.05$ & $72.00 \pm 7.61$ & $\mathrm{P}>0.05$ & $P>0.05$ \\
\hline
\end{tabular}

The inter-group comparison of diastolic blood pressure between Group MK and Group $\mathrm{K}$ showed no significant difference throughout study. Thus less fluctuation in diastolic blood pressure occurred in patients of Group K. While patients in Group MK showed significant fall in diastolic blood pressure. 
Table 4A: Changes in Mean Respiratory Rate

\begin{tabular}{|c|c|c|c|c|c|}
\hline T IME & $\begin{array}{l}\text { GROUP MK } \\
\text { RESPIRAT ORY } \\
\text { RATE } \\
(\text { RATE } / M I N) \\
(\text { MEAN } \pm \text { SD) }\end{array}$ & $\begin{array}{l}\text { INTRA-GROUP } \\
\text { COMPARISON } \\
\text { P VALUE } \\
\text { SIGNIFICANCE }\end{array}$ & $\begin{array}{l}\quad \text { GROUP K } \\
\text { RESPIRATORY } \\
\text { RATE } \\
(\text { RATE/MIN) } \\
(\text { MEAN } \pm \text { SD) } \\
\end{array}$ & $\begin{array}{l}\text { INTRA-GROUP } \\
\text { COMPARISON } \\
\text { P VALUE } \\
\text { SIGNIFICANCE }\end{array}$ & $\begin{array}{l}\text { INTER-GROUP } \\
\text { COMPARISON } \\
\text { P VALUE } \\
\text { SIGNIFICANCE }\end{array}$ \\
\hline $\begin{array}{l}\text { PRE } \\
\text { BLOCK }\end{array}$ & $14.60 \pm 0.93$ & & $14.47 \pm 0.86$ & & $\mathrm{p}>0.05$ \\
\hline \multicolumn{6}{|c|}{ POST BLOCK } \\
\hline $1 \mathrm{MIN}$ & $14.60 \pm 0.93$ & $\mathrm{p}>0.05$ & $14.47 \pm 0.86$ & $p>0.05$ & $p>0.05$ \\
\hline $5 \mathrm{MIN}$ & $14.46 \pm 0.86$ & $p>0.05$ & $14.47 \pm 0.86$ & $p>0.05$ & $p=0.05$ \\
\hline $10 \mathrm{MIN}$ & $14.50 \pm 0.86$ & $\mathrm{p}>0.05$ & $14.40 \pm 0 . .81$ & $\mathrm{p}>0.05$ & $p>0.05$ \\
\hline $15 \mathrm{MIN}$ & $14.50 \pm 0.86$ & $p>0.05$ & $14.40 \pm 0.81$ & $\mathrm{p}>0.05$ & $p=0.05$ \\
\hline $30 \mathrm{MIN}$ & $14.43 \pm 0.82$ & $p>0.05$ & $14.40 \pm 0.81$ & $p>0.05$ & $p>0.05$ \\
\hline $60 \mathrm{MIN}$ & $14.43 \pm 0.82$ & $p>0.05$ & $14.40 \pm 0.81$ & $p>0.05$ & $p>0.05$ \\
\hline $90 \mathrm{MIN}$ & $14.43 \pm 0.82$ & $p>0.05$ & $14.40 \pm 0.81$ & $p>0.05$ & $p>0.05$ \\
\hline $120 \mathrm{MIN}$ & $14.43 \pm 0.82$ & $p>0.05$ & $14.40 \pm 0.81$ & $p>0.05$ & $p=0.05$ \\
\hline $150 \mathrm{MIN}$ & $14.43 \pm 0.82$ & $p>0.05$ & $14.40 \pm 0.81$ & $p>0.05$ & $p=0.05$ \\
\hline
\end{tabular}

On intra and inter group comparison, there was no significant change in mean respiratory rate from its pre block value at any given time of study.
Thus respiratory depression as per respiratory rate criteria did not occur in any case in either of the group.

Table 4B: Changes in Mean Oxygen Saturation

\begin{tabular}{|c|c|c|c|c|c|}
\hline \multirow[b]{2}{*}{ TIME } & \multicolumn{2}{|c|}{ GROUP MK } & \multicolumn{2}{|l|}{ GROUP K } & \multirow[b]{2}{*}{$\begin{array}{l}\text { INTER- GROUP } \\
\text { COMPARISON } \\
\text { P VALUE } \\
\text { SIGNIFICANCE }\end{array}$} \\
\hline & $\begin{array}{l}\text { OXYGEN } \\
\text { SATURATION } \\
\% \\
(\text { MEAN } \pm \text { SD) }\end{array}$ & $\begin{array}{l}\text { INTRA-GROUP } \\
\text { COMPARISON } \\
\text { P VALUE } \\
\text { SIGNIFICANCE }\end{array}$ & $\begin{array}{l}\text { OXYGEN } \\
\text { SATURATION } \\
\% \\
(\text { MEAN } \pm \text { SD) }\end{array}$ & $\begin{array}{l}\text { INTRA-GROUP } \\
\text { COMPARISON } \\
\text { P VALUE } \\
\text { SIGNIFICANCE }\end{array}$ & \\
\hline $\begin{array}{l}\text { PRE } \\
\text { BLOCK }\end{array}$ & $98.80 \pm 0.45$ & & $98.67 \pm 0.55$ & & $p>0.05$ \\
\hline \multicolumn{6}{|c|}{ POST BLOCK } \\
\hline $1 \mathrm{MIN}$ & $98.77 \pm 0.47$ & $\mathrm{p}>0.05$ & $98.67 \pm 0.55$ & $\mathrm{p}>0.05$ & $p>0.05$ \\
\hline $5 \mathrm{MIN}$ & $98.73 \pm 0.48$ & $p>0.05$ & $98.67 \pm 0.55$ & $p>0.05$ & $p>0.05$ \\
\hline $10 \mathrm{MIN}$ & $98.73 \pm 0.48$ & $p>0.05$ & $98.70 \pm 0.47$ & $\mathrm{p}>0.05$ & $p>0.05$ \\
\hline $15 \mathrm{MN}$ & $98.77 \pm 0.47$ & $p>0.05$ & $98.70 \pm 0.47$ & $\mathrm{p}>0.05$ & $p>0.05$ \\
\hline $30 \mathrm{MN}$ & $98.79 \pm 0.45$ & $p>0.05$ & $98.70 \pm .47$ & $p>0.05$ & $p>0.05$ \\
\hline $60 \mathrm{MIN}$ & $98.83 \pm 0.43$ & $p>0.05$ & $98.70 \pm 0.47$ & $p>0.05$ & $p>0.05$ \\
\hline $90 \mathrm{MIN}$ & $98.83 \pm 0.43$ & $p>0.05$ & $98.70 \pm 0.47$ & $\mathrm{p}>0.05$ & $p>0.05$ \\
\hline $120 \mathrm{MIN}$ & $98.83 \pm 0.43$ & $p>0.05$ & $98.70 \pm 0.47$ & $p>0.05$ & $p>0.05$ \\
\hline $150 \mathrm{MN}$ & $98.83 \pm 0.43$ & $p>0.05$ & $98.70 \pm 0.47$ & $p>0.05$ & $p>0.05$ \\
\hline
\end{tabular}

On intra and inter group comparison, there was no significant change in mean oxygen saturation from its pre block value at any given time of study.
Thus respiratory depression as per oxygen saturation criteria did not occur in any case in either of the group.

Table 5: Assessment of Sedation

\begin{tabular}{l|c|cc}
\hline \multicolumn{1}{c|}{ Sedation Score } & Group MK & Group K & P Value Significance \\
\hline Grade 0 & 4 & 30 & $\mathrm{P}<0.001$ \\
\hline Grade 1 & 26 & 0 & $\mathrm{P}<0.001$ \\
Grade 2 & 0 & 0 & - \\
Grade 3 & 0 & 0 & -
\end{tabular}

Addition of midazolam to ketamine and bupivacaine provided mild sedation in Group MK patients. 
Table 6: Pain Relief

\begin{tabular}{lc|cc|}
\hline & GROUP MK & GROUP K & $\begin{array}{c}\text { P VALUE } \\
\text { SIGNIFICANCE }\end{array}$ \\
\hline $\begin{array}{l}\text { DURATION OF PAIN FREE } \\
\text { INTERVAL (MIN) (MEAN } \pm \text { SD) }\end{array}$ & $594 \pm 63.39$ & $421.67 \pm 38.42$ & $\mathrm{P}<0.001$ \\
\hline $\begin{array}{l}\text { ANALGESIC REQU IREMENT IN } \\
\text { 24HR POST OP PERIOD }\end{array}$ & $1.43 \pm 0.63$ & $2.4 \pm 0.62$ & $\mathrm{P}<0.001$ \\
\hline
\end{tabular}

The difference was statistically highly significant. Thus addition of midazolam to ketamine and bupivacaine prolong the duration of pain free interval and decrease the analgesic requirement in post operative period.

Table 7A: Intra operative Complications

\begin{tabular}{|lcc|}
\hline NTRA-OPERAT IVE & GROUP MK & GROUP K \\
HYPOTENSION & $\mathbf{5}$ & Nil \\
\hline BRADYCARDIA & Nil & Nil \\
\hline NAUSEA/VOMITING & Nil & Nil \\
\hline SHIVERING & Nil & Nil \\
HALLUCINATION/ & Nil & Nil \\
EMERGENCE PHE NOMENA & & \\
\hline RESPIRATORY DEPRESSION & Nil & Nil \\
OTHERS & Nil & Nil
\end{tabular}

Table 7B: Postoperative Complictions

\begin{tabular}{l|c|c}
\hline $\begin{array}{l}\text { POST-OPERATIVE } \\
\text { HYPOTENSION }\end{array}$ & $\begin{array}{c}\text { GROUP MK } \\
\text { Nil }\end{array}$ & $\begin{array}{c}\text { GROUP K } \\
\text { Nil }\end{array}$ \\
\hline BRADYCARDIA & Nil & Nil \\
\hline NAUSEA/VOMITING & Nil & Nil \\
\hline SHIVERING & Nil & Nil \\
HALLUCINATION/EMERGENCE & Nil & Nil \\
PHENOMENA & & \\
\hline URINARY RETENSION & Nil & Nil \\
OTHER BEHAVIORAL AND & Nil & Nil \\
NEUROLOGICAL COMPLICATION & & \\
\hline
\end{tabular}

\section{Discussion}

Spinal anaesthesia is often used for both elective and emergency lower abdominal and lower limb surgeries. One of the most commonly used local anaesthetic agents in spinal anaesthesia for long surgeries is Bupivacaine. The disadvantage with spinal anaesthesia using bupivacaine alone is a relatively slow onset of action and short duration of post operative analgesia, which means that early analgesic intervention, may be needed in post operative period. Another problem associated with bupivacaine in spinal anaesthesia is hypotension. Efforts have therefore always been made to improve quality, augment the duration of anaesthesia and analgesia produced by local anaesthetics in spinal anaesthesia with minimal haemodynemic alteration and other side effects.

There is evidence from animal studies that ketamine produce sensory and motor blocks when injected intrathecally. Preservative free ketamine is introduced as a sole spinal anaesthetic agent more than 20 years ago and found to have advantage over local anaesthetic agents in that it provide cardiovascular stability. It was first time used as a sole spinal anaesthetic agent by Dr Bion during war in patients undergoing surgeries for lower limb injuries. Studies by Hawksworth and Serpell, Kathirvel et al, Kaliyani et al showed 
psychomimetic disturbances and CNS side effects and thus precluded its use as a sole agent for spinal anaesthesia. Surgical analgesia and motor blocked produced by ketamine is also found to have shorter duration. The amount of ketamine to be added to bupivacaine is also important. Review of literature shows the use of intrathecal ketamine in dose varying from 5-100mg. Studies in which ketamine was used in higher doses such as Kathirvel et al (25mg), Bion JF (5-50mg), Hawksworth and Serpell (0.75-0.9mg/kg), Kaliyani et al (75-100mg), Aloka et al (100mg) were associated with increased incidence of neurological complication like sedation, dizziness, nystagmus and in severe cases emergence reaction. However, Togal et al and T M Krishna et al used ketamine intrathecally in very low dose $0.1 \mathrm{mg} / \mathrm{kg}$ and did not come across any side effects with stable haemodynemics with decreased incidence of hypotension. Therefore, in our study we decided to use very low dose of ketamine $(0.1 \mathrm{mg} / \mathrm{kg})$ with bupivacaine to see whether it provide stable haemodynemic or not and produce any neurological side effects.

Addition of intrathecal midazolam to hyperbaric bupivacaine in various studies Kim and Lee (1$2 \mathrm{mg})$, N Bharti et al (1mg), Nidhi Agrawal et al $(1 \mathrm{mg})$, and T M Krishna et al (1mg) clearly shows significant prolongation of post-operative analgesia and pain free interval. N Bharti et al also showed that intrathecal midazolam also improves quality of spinal anaesthesia. There is controversy regarding neurotoxicity of intrathecal use of midazolam in animal studies. A cohort study of 1100 patients by Adam P Tucker et al suggest that intrathecal midazolam in dose up to $2 \mathrm{mg}$ did not increase the occurrence of neurologic or urologic complication. He advocated that $0.03 \mathrm{mg} / \mathrm{kg}$ dose of midazolam was found to be safe. In study by Mi Ja Yun et al, they showed that intrathecal addition of more than $2 \mathrm{mg}$ midazolam require more rigorous attention due to its sedative effect particularly in old and vulnerable patients. Hence, we decided to use midazolam in low and safe dose range $20 \mu \mathrm{g} / \mathrm{kg}$ in our study.
Regarding the use of combination of low dose of midazolam and ketamine with bupivacaine, we came across only one study by $\mathrm{T}$ M Krishna et al (2008) and we decided to study to evaluate the effect of addition of low dose midazolam to a mixture of low dose ketamine and hyperbaric bupivacaine when given intrathecally in patients undergoing lower limb orthopaedic surgery.

This combination may provide stable hemodynamics with fewer fluctuations in blood pressure and prolongation of pain free interval and may help to overcome this major problems associated with intrathecal use of bupivacaine.

Demographic Data: The two groups are comparable to each other with respect to age, sex, height, weight and ASA status. Furthermore, all the patients included in the study were of ASA 1 status in both groups. Sex ratio $\mathrm{M}: \mathrm{F}$ is also comparable between two groups.

Block characteristics: The sensory block was assessed in our study by using pin prick method along mid-axillary line. Our result in this regard was in resemblance with those of T M Krishna et al (2008) who also reported significantly quick onset of sensory block in midazolam-ketaminebupivacaine group as compared to ketaminebupivacaine group. The quick onset of sensory block indicates synergistic effect between intrathecal midazolam and bupivacaine, though mechanism of action may be different. The local anaesthetic bupivacaine blocks voltage gated sodium channel while midazolam act on benzodiazepine- GABA-A receptor complex at dorsal horn of spinal cord. Thus, combined action of two receptor based system in spinal cord is useful as shown by Tucker et al. Contrary to our study, Nidhi Agrawal et al (2005) in their study showed that no difference in the onset of sensory block by addition of midazolam to bupivacaine.

The duration of sensory block in our study was in resemblance to that of TM Krishna et al (2008) who also noticed significant prolongation of sensory block in midazolam-ketaminebupivacaine group as compared to ketaminebupivacaine group. Kathirvel et al (2000) in their 
study showed that no significant difference occur in duration of sensory block with addition of ketamine to bupivacaine while Bharti $\mathrm{N}$ et al (2003) and Mia JY et al (2007) in their study showed that significant prolongation in duration of sensory block occur with addition of midazolam to bupivacaine.

Reason for short duration of sensory block in Group K may be due to shorter duration action of ketamine as compared to bupivacaine. In Group MK sensory duration prolongation might be because of synergy of action between intrathecal midazolam, ketamine and bupivacaine.

In contrary to our study, Nidhi Agrawal et al (2005) showed no difference in duration of sensory block occur with addition of midazolam to bupivacaine.

Motor Block was assessed by using Bromage score. Onset of motor block was defined as time interval between intrathecal drug administrations to when Bromage grade become 3. The mean time for onset of motor block was $6.03 \pm 1.13 \mathrm{~min}$ in Group MK as compared to $7.30 \pm 1.06 \mathrm{~min}$ in Group K. This difference is statistically also significant $(p<0.001)$. All the patients in both group attained Bromage grade 3. Our result is comparable with those of TM Krishna et al (2008), Kathirvel et al (2000) and Bharti N et al (2003).

Duration of motor block in our study was in consonance with that of TM Krishna et al (2008) who also showed prolongation of motor block in midazolam-ketamine-bupivacaine group as compared to ketamine-bupivacaine group. Bharti $\mathrm{N}$ et al (2003) in their study also showed prolongation of motor block with addition of midazolam to bupivacaine. Kathirvel et al (2000) in their study showed that duration of motor blockade was shorter in ketamine-bupivacaine group as compared to bupivacaine alone.

Spinal anaesthesia produce sensory, motor and sympathetic blockade. Sympathetic blockade may produce hypotension and changed in pulse rate. There may be bradycardia or tachycardia during surgery. Normally the fall in blood pressure is within $20 \%$ of preoperative value, if the patient is properly hydrated and block is not very high, therefore adequate preloading before giving spinal block is necessary. In our study, we gave injection ringer lactate $10 \mathrm{ml} / \mathrm{kg}$ for preloading.

As shown by Bion JF, Kaliyani et al and Kathirvel et al intrathecal Ketamine produce stable haemodynamics while Mi Ja Yun et al, N Bharti et al suggest that addition of Midazolam to Bupivacaine does not alter haemodynamics. In our study, addition of midazolam and ketamine in low dose to bupivacaine did not affect the pulse rate significantly.

The mean systolic blood pressure show a significant fall after 10 min of spinal block in Group MK $(\mathrm{p}<0.001)$ while no such significant fall observed in Group K. Similarly mean diastolic blood pressure also show significant fall among Group MK $(\mathrm{p}<0.005)$ while diastolic blood pressure remain stable in Group K. Our results are consistent with those of T M Krishna et al (2008) who also showed stable haemodynamics with decrease incidence of hypotension in ketaminebupivacaine group as compared to midazolamketamine-bupivacaine group. N Bharti et al (2003) showed that changes in blood pressure and pulse rate were comparable between midazolambupivacaine and bupivacaine alone group. Kathirvel et al (2000) also showed that patients in ketamine-bupivacaine group had significantly higher systolic and diastolic blood pressure after induction of spinal anaesthesia and also volume of intravenous fluid required to maintain blood pressure was lower in ketamine-bupivacaine group. Kaliyani et al (2001) in their study also showed that intrathecally administered ketamine caused dose dependent mild increase in pulse rate and systolic blood pressure. Upadhyay et al (1998) in their study also showed that intrathecal ketamine provides stable haemodynamics. Bion JF et al (1984) and Togal $\mathrm{T}$ et al (2004) also showed stable haemodynamic with intrathecal use of ketamine.

It may be due to diffusion of ketamine into venous system (azygous vein) of spinal cord which in turn 
results in cardiovascular stimulation and haemodynamic stability after spinal anaesthesia. Midazolam did not prevent the haemodynamic instability produced by intrathecal bupivacaine.

Sedation in our study was assessed by using four point sedation scoring system. No patients in Group $\mathrm{K}$ and 4 patients in Group MK had no sedation (Grade 0). While 26 patients in Group MK had Grade 1 sedation i.e. Asleep but easily arousable by using verbal command. Thus, addition of midazolam provided mild sedation in majority of patients in Group MK. In this all cases effect of sedation resolved within an hour.

Our result in this regard is in resemblance to the study of T M Krishna (2008). Yegin et al (2004) also reported sedative scales were significantly higher in bupivacaine plus midazolam group compared to bupivacaine alone group. However, N Bharti et al (2003) and Mi Ja Yun et al (2007) reported that the sedative score were comparable in both groups.

The onset of sedative effects of intrathecal midazolam seemed to slower than intravenous midazolam. It may be due to cephalad spread in CSF or systemic absorption may contribute. In our study, we use ketamine in very low dose $0.1 \mathrm{mg} / \mathrm{kg}$ which may explain no sedation observed in patients of Group K.

Post operative pain assessment in our study was done by using visual analogue scale. Our results were in consonance with by $\mathrm{T}$ M Krishna et al (2008). Kathirvel et al (2000) in their study showed that addition of ketamine to bupivacaine did not provide extended post-operative analgesia or decrease in postoperative analgesic requirements. M H Kim and Lee (2001), N Bharti et al (2003), B Jahangiri et al (2006), Nidhi Agrawal et al (2005) showed in their study that there was significant prolongation of pain free interval and less post operative analgesic requirement with addition of midazolam to bupivacaine. This might be because of synergy of action between intrathecal midazolam, ketamine, and bupivacaine. Analgesic effect of intrathecal bupivacaine was potentiated by intrathecal midazolam in dose dependent manner as suggested by M H Kim and Lee (2001). Midazolam involved in pain modulation by acting on benzodiazepine receptors in lamina 2 of dorsal horn in human spinal cord. Intrathecal midazolam is also involved in release of an endogenous opioids acting at spinal $\delta$ receptors.

In our study we considered hypotension when systolic blood pressure was $<20 \%$ of pre-block value after spinal injection. In our study 5 patients in Group MK developed hypotension while no patient in Group $\mathrm{K}$ had hypotension. Our results are in consonance with the study of T M Krishna et al (2008) who showed no vasopressure required in ketamine-bupivacaine group while $10 \%$ of patients in midazolam-ketamine-bupivacaine group required vasopressure to treat hypotension. Kathirvel et al (2000) showed in their study that patients in ketamine-bupivacaine group required less intravenous fluid to maintain blood pressure.

No patients from either group had developed bradycardia, respiratory depression, nausea and vomiting, urinary retention and shivering during the intra or post operative period.

Neurological and behavioural side effects were assessed by clinical signs in our study includes pain, motor and sensory deficits, bowel and bladder disturbances, emergence delirium. They were not observed in any of the patients till they were discharged from our hospital. Bion JF (1984), Hawksworth et al (1992), Kathirvel et al (2000), Aloka S et al (2006), Kaliyani G et al (2001) used ketamine in higher doses and showed higher incidence of neurological and behavioural side effects. In our study we used very low dose of ketamine which may be a reason for non occurrence of neurological and behavioural side effects in our study.

\section{Conclusion}

Combination of Ketamine in low dose $(0.1 \mathrm{mg} / \mathrm{kg})$ with Bupivacaine heavy $0.5 \%$ (3ml) provides stable haemodynemics without any behavioural and central side effects. Addition of Midazolam in low dose $(20 \mu \mathrm{g} / \mathrm{kg})$ to a mixture of low dose 
Ketamine $(0.1 \mathrm{mg} / \mathrm{kg})$ and Bupivacaine heavy $0.5 \%(3 \mathrm{ml})$ when given intrathecally influence the sensory and motor block by shortening the onset time and prolonging the duration of surgical anaesthesia and pain free interval without affecting the other parameters and complications of subarachnoid block.

\section{References}

1. Aloka S, Hanumantha MR. Evaluation of midazolam as an additive to intrathecal ketamine. J Anaesth Clin Pharmacol 2006; 22(4): 363-369.

2. Bharti N, Madan R, Mohanty PR, Kaul HL. Intrathecal midazolam added to bupivacaine improves the duration and quality of spinal anaesthesia. Acta Anaesthesiol Scand 2003; 47: 1101-1105.

3. Bion JF. Intrathecal ketamine for war surgery. A preliminary study under field condition. Anaesthesia 1984; 39: 10231028.

4. Dipasri B, Arnab B. A comparative study of clinical effects of intrathecal hyperbaric bupivacaine and ketamine in hyperbaric solution. Indian J Anaesth 2004; 48(2): 116-120.

5. Goodchild CS, Guo Z, Musgreave A, Gent JP. Antinociception by intrathecal midazolam involves endogenous neurotransmitters acting at spinal cord delta opioid receptors. Br J Anaesth 1996; 77: 758-763.

6. Goodchild CS, Nobel J. The effects of intrathecal midazolam on sympathetic nervous system reflexes in man: a pilot study. Br J Clin Pharmacol 1987; 23: 279285.

7. Hodgson PS, Neal JM, Pollock JE, Liu SS. The neurotoxicity of drug given intrathecally (spinal). Anesth Analg 1999; 88: 797-809.

8. Hawksworth C, Serpell M. Intrathecal anaesthesia with ketamine. Reg anaesthesia 1992; 69: 292-297.
9. Jahangiri B, Jahangiri R. Intrathecal midazolam prolongs the analgesic effects of spinal blockade with lidocaine for perineal operation. Acta Medica Iranica 2006; 44(5): 354-356.

10. Kaliyani G, Rajmani K, Marc PK, Rafik M, Richard JF, Jonas G. Intrathecal ketamine in surgeries for lower abdomen and lower extremities. Proc West Pharmacol Soc 2001; 44: 197-199.

11. Kathirvel S, Sadhasivam S. Effect of intrathecal ketamine added to bupivacaine for spinal anaesthesia. Anaesthesia 2000; 55: 899-910.

12. Kim MH, Lee YM. Intrathecal midazolam increase the analgesic effects of spinal blockade with bupivacaine in patients undergoing haemorrhoidectomy. $\mathrm{Br} \quad \mathrm{J}$ Anaesth 2001; 86: 77-79.

13. Mi JY, Yoon HK, Jin HK, Kyoung OK, Aa YO, Hee PP. Intrathecal midazolam added to bupivacaine prolongs the duration of spinal blockade to T10 dermatome in orthopaedic patients. Korean $\mathrm{J}$ anesthesiol 2007; 53:S22-28.

14. Nidhi A, Usmani A, Sehgal R, Rakesh K, Poonam B. Effect of intrathecal midazolam bupivacaine combination on post operative analgesia. Indian J Anaesth 2005; 499(1): 37-39.

15. Nishiyama T, Hanaoka K. Midazolam can potentiate the analgesic effects of intrathecal bupivacaine on thermal or inflammatory induced pain. Anaesth analg 2003; 96: 1386-1391.

16. Richard FC, Marc AC. The effects of benzodiazepines on human opioid receptor binding and function. Anesth Analg 2001; 93: 354-358.

17. TM Krishna, NB Panda, YK Batra, S Rajeev. Combination of low doses of intrathecal ketamine and midazolam with bupivacaine improves postoperative analgesia in orthopaedic surgery. Eur $\mathbf{J}$ Anaesthesiol 2008; 25: 299-306. 
18. Togal T, Demirbilik S, Koroglu A, Yapici E, Ersoy O. Effects of S (+) ketamine added to bupivacaine for spinal anaesthesia for prostate surgery in elderly patients. Eur J Anaesthesiol 2004; 21: 193197.

19. Tucker AP, Cindy L, Raymond N, Goodchild CS. Intrathecal midazolam I: A cohort study investigating safety. Anaesth analg 2004; 98: 1512-1520.

20. Tucker AP, Joseph M, Raymond N, Goodchild CS. Intrathecal midazolam II: combination with intrathecal fentanyl for labor pain. Anaesth analg 2004; 98: 15211527.

21. Upadhyay MR, Desai DJ, Swadia VN. Intrathecal ketamine for surgery. Indian $\mathbf{J}$ Anaesth 1998; 42(6): 70-72.

22. Yegin A, Sanli S, Dosemeci L, Kayacan N, Akbas M, Karsli B. The analgesic and sedative effects of intrathecal midazolam in perianal surgery. Eur $\mathrm{J}$ Anaesthesiol 2004; 21: 658-662. 